\title{
Effectiveness of Discharge Planning Programs to Increase Maternal Self-Efficacy in the Prevention of Diarrhea: A Randomized Controlled Trial
}

\author{
$1^{\text {st }}$ Nurlaila \\ STIKES Muhammadiyah Gombong \\ Kebumen, Indonesia \\ nurlaila@stikesmuhgombong.ac.id
}

\author{
$2^{\text {nd }}$ Wuri Utami \\ STIKES Muhammadiyah Gombong \\ Kebumen, Indonesia
}

\author{
$3^{\text {rd }}$ Lili Nurnaningsih \\ RSUD Dr. Soedirman Kebumen, \\ Kebumen, Indonesia
}

\begin{abstract}
Background: Diarrhea is a problem of health that often occurs in children. Untreated diarrhea can lead to death due to dehydration. Children experiencing diarrhea should be properly cared for to overcome dehydration and prevent its recurrence. Such abilities should be demonstrated by mothers who have children under five years. Discharge planning programs in hospitals can increase maternal knowledge and readiness in caring for children with diarrhea. Purpose: The purpose of this study was to determine the effectiveness of discharge planning programs on maternal self-efficacy in the prevention of diarrhea in children. Methods: This study used a pretest-posttest quasiexperimental design with a control group. The samples were 60 mothers of children aged 0-5 years old undergoing treatment in the hospital due to diarrhea. The samples were randomly recruited and assigned to the intervention group $(n=30)$ that received discharge planning programs during treatment and the control group $(n=30)$ that received health education based on hospital standards. The data were collected using the Self-Efficacy Scale for Preventing Early Childhood Diarrhea and analyzed using the independent $t$ test. Results: Results of the study indicated that discharge planning programs were effective in increasing maternal selfefficacy in the prevention of diarrhea with a p-value of 0.000 and a mean difference of 29.533. After the intervention, the mean score of maternal self-efficacy in the intervention group and the control group was 106.60 (high) and 77.7 (moderate), respectively. Conclusion: Discharge planning programs could increase maternal self-efficacy in the prevention of diarrhea. Structured discharge planning programs can provide ease for mothers to receive the information needed during the treatment.
\end{abstract}

Keywords-Discharge planning, diarrhea, self-efficacy

\section{INTRODUCTION}

Diarrhea is such a disease that frequently occurs in children in Indonesia. Diarrhea can cause dehydration that leads to death. Data from the Indonesian Demographic and Health Survey [1] showed that $14 \%$ of children under five had suffered from diarrhea for the past two weeks prior to the survey. Five per 1,000 children suffer from diarrhea accompanied by blood. The prevalence of diarrhea in children aged 6-23 months is around 19-20\%.

The causes of diarrhea can be clinically divided into six groups: infections (caused by bacteria, viruses, or parasite), malabsorption, allergies, poisoning, immunodeficiency, and other causes. Most diarrhea in the community or clinical settings occurs due to infections and poisoning. An infection in the digestive tract can be affected by children's personal hygiene, food hygiene, maternal knowledge about the prevention of diarrhea, and environmental hygiene. It is consistent with a study by Amaliah (2010), which stated that there is a relationship between environmental and cultural sanitation and the incidence of diarrhea. Poor environmental sanitation may present in the form of unclosed latrines, the habit of defecation in places other than toilets, and shallow drinking water sources. Community cultures that support the incidence of diarrhea include the habit of drinking raw water, washing hands without soap, and false perceptions of diarrhea in children under five. Data from the Indonesian Demographic and Health Survey [1] showed that the prevalence of diarrhea is highest $(19 \%)$ in children in households without latrines (defecating in rivers).

The prevention of diarrhea by mothers is done through exclusive breastfeeding, providing balanced nutritional food, washing fruits and vegetables before cooking and eating, washing hands with water and soap, giving breast milk, immunization for children, and consuming healthy drinking water [3]. Such preventions of diarrhea and other interventions to reduce morbidity and mortality due to diarrhea will be effective if they are adjusted to the level of maternal self-efficacy in the prevention of diarrhea [4]. Maternal self-efficacy is a fundamental asset for the treatment of diarrhea with oral rehydration salts (ORS) and zinc that are evident to be effective in reducing high mortality rate due to diarrhea by $40 \%$. A study reported that the use of zinc with ORS reduced $5 \%$ of total medical costs 
and 17 hours of acute diarrhea [5]. The use of zinc and probiotics in diarrhea has a significant effect on feces consistency, frequency and duration of diarrhea, and length of stay [6]. The use of ORS in managing diarrhea in the Indonesian population is $33.3 \%$. In Central Java, the use of zinc and ORS in the treatment of diarrhea is $14.6 \%$ and $23.1 \%$, respectively. Zinc is administered to children with diarrhea for ten days. However, based on the data from [1], $36 \%$ of children under five have ORS when they suffer from diarrhea, $19 \%$ are given a self-made salt sugar solution, and $47 \%$ drink more water. The successful administration of zinc and ORS to children is strongly influenced by maternal adherence in the care of diarrhea. Mothers or parents of children with diarrhea should be given health education about its treatment at home and the main principles of the prevention, which can be done by nurses through discharge planning programs.

The purpose of discharge planning is to reduce the length of stay in the hospital, prevent a disease recurrence, and improve service coordination after the treatment in the hospital [7]. Furthermore, [8] stated that discharge planning affected maternal knowledge in caring for children with diarrhea in PKU Muhammadiyah Hospital, Yogyakarta. Discharge planning can provide motivation for patients to recover, shorten the length of stay, and decrease the level of patient relapse. A study by Rofii et al. (2012) showed that there is a relationship between personnel of discharge planning, involvement and participation, communication, agreements and consensus, and the implementation of patient discharge planning.

Discharge planning programs begin when a patient arrives at the hospital. The initial steps in implementing discharge planning include the identification of the patient's condition, identification of the patient's discharge planning needs, and the arrangement of patient care planning (Peate et al., 2014). However, discharge planning programs have not been well implemented in all settings of patient services in hospitals. Research showed that the implementation of discharge planning by nurses at the assessment stage and the implementation stage with a good category was $63.1 \%$ and $58.5 \%$, respectively, of total respondents [9]. It frequently happens that many nurses provide health education at the time when the patient will be discharged. In their study, [10] identified that the needs of patients consisted of three main categories, i.e., the need for disease information and its treatment, the need for services by doctors, nurses and nutritionists, and the need for discharge planning program which include the time, place, method and media. The purpose of this study was to determine the effectiveness of discharge planning programs on maternal self-efficacy in preventing diarrhea in children.

\section{METHODS}

The present study used a pretest-posttest quasiexperimental research design with a control group. The samples were mothers of children aged 1 month to 5 years old who underwent treatment at RSUD Dr. Soedirman, Kebumen. The samples were randomly selected and divided into the intervention group $(n=30)$ that received discharge planning programs and the control group $(n=30)$ that received standard health education based on the hospital procedures. The data collection was carried out using a double-blind method.

Maternal self-efficacy in the prevention of diarrhea was measured before and after the intervention using the Selfefficacy Scale for Preventing Early Childhood Diarrhea (Joventino et al., 2012). Based on the results of the research entitled "The Maternal Self-efficacy Scale for Preventing Early Childhood Diarrhea: Validity and Reliability," it was shown that the high predictive validity result indicates that self-efficacy is a factor that causes diarrhea in children. The reliability test of this instrument showed a score of 0.84 .

The instrument was translated from English to Indonesian. The process of language validity and reliability testing was carried out by English language experts in two stages. The first stage was a back-translation of the questionnaire from English to Indonesian, and the second stage was a back-to-back translation from Indonesian to English. The result showed no significant discrepancies between the English and Indonesian versions of the questionnaire. The collected data were tested for normality using the Shapiro Wilk test, and the result showed that the data were normally distributed. A further statistical analysis using the independent t-test was performed. This research had been reviewed and approved by the research ethics committee of STIKES Muhammadiyah Gombong No.495.6/IV.3.AU/F/ETIK/XII/2019.

\section{RESULTS AND DISCUSSION}

The respondents in this study were mothers of children undergoing treatment in the hospital (30 mothers each in the intervention group and the control group). Patients undergoing treatment in the pediatric unit of RSUD Dr. Soedirman were screened and examined whether they met the inclusion criteria. Those who met the criteria and were willing to be respondents were asked to take a lottery to determine whether they belonged to the intervention group or the control group. All respondents were requested to fill out the maternal self-efficacy questionnaire in the prevention of diarrhea on the first day of the intervention. Respondents in the intervention group were given the following programs of discharge planning:

Day 1: Assessment of patient needs

Day 2: Health education about care for children with diarrhea

Day 3: Health education about medicine and nutrition for children with diarrhea

Day 4: Health education about when patients should be taken to the hospital

The methods used in the administration of health education were lectures and demonstrations, while the supporting media included booklets, leaflets, and equipment for caring diarrhea in children.

On the other hand, respondents in the control group were given health education about diarrhea based on the hospital procedures at the time the patients were discharged. Before leaving the hospital, the respondents were asked to fill in the maternal self-efficacy questionnaire for diarrhea prevention. The data collection process was carried out using a double-blind method. 


\section{A. Characteristics of Children}

TABLE I. CHARACTERISTICS OF CHILDREN WITH DIARRHEA $(N=60)$

\begin{tabular}{|l|c|c|c|c|}
\hline \multirow{2}{*}{ Variables } & \multicolumn{2}{|c|}{ Intervention Group } & \multicolumn{2}{c|}{ Control group } \\
\cline { 2 - 5 } & $f$ & $(\%)$ & $f$ & $(\%)$ \\
\hline Age & & 16.7 & 6 & 20 \\
\hline 6-12 months & 5 & 40 & 12 & 40 \\
\hline $13-24$ months & 12 & 43.3 & 12 & 40 \\
\hline 25-60 months & 13 & & & 60 \\
\hline Gender & & 53.3 & 18 & 40 \\
\hline Male & 16 & 46.7 & 12 & 6 \\
\hline Female & 14 & & & \\
\hline
\end{tabular}

Table 1 shows that most children were aged 25-60 months old. Children of this age are in the late development of toddler until preschool. In this stage, children have already consumed a variety of foods. Regarding rough motoric skills, children are able to walk upstairs. In terms of fine motoric skills, children at this stage begin to learn to use colored pencils, explore the environment and initiate something, have imagination, and develop skills through active play and work together. As a result, they have the risk of exposure to pathogenic microorganisms that enter their digestive tract. This is consistent with the research of Dwi Sulistyo C, which revealed that mother respondents who have children with pneumonia in hospitals were at toddler age. The results of this study are different from the number of hospitalized children in public health centers in Pekanbaru, which are mostly 1-3 years of age [11]. Most children with diarrhea in this study are boys. Boys like to make more movements, such as kicking balls, than girls. This is consistent with the results of a study by Maryanti et al. (2017) which showed that the majority of children undergoing treatment at the public health centers in Pekanbaru were suffering from diarrhea and were boys $(54.2 \%)$. In contrast, a study by Yusuf (2016) reported that the number of girls and boys with diarrhea was $51.9 \%$ and $48.1 \%$, respectively. No scientific evidence has been found about the risk of diarrhea in boys and girls.

\section{B. Characteristics of Mothers}

TABLE II. CHARACTERISTICS OF MOTHERS $(N=60)$

\begin{tabular}{|l|c|c|c|c|}
\hline \multirow{2}{*}{ Age } & \multicolumn{2}{|c|}{ Intervention group } & \multicolumn{2}{c|}{ Control group } \\
\cline { 2 - 5 } & $f$ & $\%$ & $f$ & 56.7 \\
\hline 22-30 years old & 13 & 43.3 & 17 & 36.7 \\
\hline 31-40 years old & 15 & 50.0 & 11 & 6.7 \\
\hline 41-50 years old & 2 & 6.7 & 2 & 100 \\
\hline Total & 30 & 100 & 30 & \\
\hline
\end{tabular}

Most mothers in the intervention group were aged 31 to $40(50.0 \%)$, while in the control group, most of them were aged 22 to $30(56.7 \%)$. A majority of mothers were in the early adulthood, i.e., 18 to 35 . According to Erikson, the main task of adulthood age is to achieve generativity. Generativity is the desire to care and guide others such as children or their peers, or provide guidance in social interaction with this generation. This is in line with a study by Sulistyo, Nurhaeni, and W (2019) which found that most mothers with pneumonia children are at the age of 35 . This adult age is the proper age to care for children under C. Normality Test five. Mothers will raise and guide the child to interact with others. Parents in adulthood can provide care for family members who are sick [14]. This is also consistent with the results of a study by Nasution, Probowati, and Khoiri (2017), which found that most parents of children with diarrhea were at the age of 20 and 35. A study by Rumbo, Wichaikull, and Sanguanprasit (2016) also found that most mothers of children undergoing treatment due to diarrhea were in the adult age of 20 to $35(73.7 \%)$.

TABLE III. RESULTS OF NORMALITY TEST

\begin{tabular}{|l|c|c|c|}
\hline \multirow{2}{*}{ Groups } & \multicolumn{3}{|c|}{ Shapiro-Wilk } \\
\cline { 2 - 4 } Control Group & Statistic & $\mathrm{df}$ & Sig. \\
\hline Intervention Group & .917 & 30 & .022 \\
\hline
\end{tabular}

The normality test in this study was performed using the Shapiro-Wilk test. The results of the test (Table III) showed that the data were normally distributed so that the bivariate analysis was carried out using the independent t-test.

\section{The effectiveness of the discharge planning programs in children with diarrhea}

TABLE IV. MEAN SCORES OF MATERNAL SELF-EFFICACY IN THE PREVENTION OF DIARRHEA AFTER THE INTERVENTION IN THE INTERVENTION GROUP AND CONTROL GROUP.

\begin{tabular}{|l|c|c|c|c|c|}
\hline Groups & $n$ & Mean & SD & Std. Error Mean & p-value \\
\hline Control Group & 30 & 77.07 & 5.614 & 1.025 & 0.000 \\
\hline Intervention Group & 30 & 106.60 & 8.857 & 1.617 & \\
\hline
\end{tabular}


The results showed that discharge planning programs were effective in increasing maternal self-efficacy in the prevention of diarrhea $(p=0.000)$. Structured and systematic discharge planning programs provided complete and easy-to-understand information for mothers who are caring for their children in the hospital due to diarrhea. Information about how diarrhea can occur in children, its causes, and how to prevent it will help mothers to prevent diarrhea in their children in the future. Mothers with good self-efficacy are most likely to apply personal and home environment hygiene, provide exclusive breastfeeding, and prepare and provide clean and healthy food. The materials provided by health professionals can improve maternal motivation and self-efficacy to adopt the desired behavior, which is to prevent diarrhea so that it can reduce morbidity in children [17]. It is congruent with a study by Suwedia and Nurwahyuni (2019), which showed that the implementation of clinical pathways applied to patients with diarrhea provides better outcomes, including shorter hospitalization, reduced treatment costs, and provide better outcomes when patients discharged. A similar thing was also reported in a study by Riyanti, Nurlaila, and Astutiningrum (2018) that breastfeeding education affects breastfeeding self-efficacy.

Most respondents in the pre-test measurement had a moderate level of self-efficacy $(83.4 \%$ in the intervention group and $80 \%$ in the control group). This can be influenced by adequate maternal knowledge about preventing diarrhea in children and proper behavior in preventing the disease. Easy access to information through social media can also affect maternal ability to prevent and treat diarrhea. Maternal experiences of having a child with diarrhea will also affect their self-efficacy in preventing diarrhea. Forbes et al. (2018) stated that the factors influencing self-efficacy are the direct experience as a result of working on a past task and the indirect experience as a result of observing the experience of others in doing the same task. The results of this study are consistent with research reporting that more than two-thirds $(68.3 \%)$ of mothers involved in the study showed good behaviors in preventing diarrhea in children aged 1-5 years in Buol Regency. Such behaviors included the consumption of safe and healthy drinking water, proper stool disposal, personal hygiene, and safe preparation and feeding practices of foods. According to the results of a survey in 2012, less than a quarter $(24.2 \%)$ of people in Buol had good behavior in practicing a hygienic and healthy lifestyle [12].

In this study, discharge planning programs were still limited to nurses. Discharge planning programs in children require the cooperation of all health workers who care for patients. The complexity of patient care requires the support of a multidisciplinary team. In the early treatment, the medical team defines care needs, divide the task of every health profession, coordinate and perform nursing rounds every week, and ensure that patients discharge from the hospital when they are ready [21].

\section{CONCLUSION}

Discharge planning programs for hospitalized children with diarrhea were effective in increasing maternal self- efficacy in the prevention of diarrhea. Maternal selfefficacy in preventing diarrhea becomes the basic capital for mothers in the implementation of diarrhea preventive behaviors in children.

\section{REFERENCES}

[1] SDKI, "Survei Demografi dan Kesehatan Indonesia," 2017.

[2] S. Amaliah, "Hubungan sanitasi Lingkungan dan Faktor Budaya dengan Kejadian Diare pada Anak Balita di Desa Toriyo Kecamatan Bendosari Kabupaten Sukoharjo," in Prosiding Seminar NAsional UNIMUS, 2010, pp. 91-97.

[3] E. S. Joventino et al., "The Maternal Self-efficacy Scale for Preventing Early Childhood Diarrhea : Validity and Reliability," 2012.

[4] A. Bandura, "Self-efficacy," Corsini Encycl. Psychol., pp. 1-3, 2010 .

[5] G. V Gregorio, L. F. Dans, C. P. Cordero, and C. A. Panelo, "Zinc supplementation reduced cost and duration of acute diarrhea in children," vol. 60, pp. 560-567, 2007.

[6] M. Lolopayung, A. Mukaddas, and I. Faustine, "Evaluasi Pengggunaan Kombinasi Zink dan Probiotik pada Penanganan Pasien Diare Anak di Instalasi Rawat Inap RSUD Undata Palu TAhun 2013," Online J. Nat. Sci., vol. 3, no. March, pp. 55-64, 2014.

[7] I. Peate, K. Wil, and M. Nair, Nursing Practice: Knowledge and Care. Oxford: Whiley Blackwell, 2014.

[8] A. Pratama, "Pengaruh Discharge planning terhdap Pengetahuan Ibu dalam Merawat Anak dengan Diare di RS PKU Muhamamdiyah Yogyakarta," Universitas Muhammadiyah Yogyakarta, 2009.

[9] M. D. Sagita, E. Y. Fitri, and A. Kusumaningrum, "Gambaran Pelaksanaan Discharge Planning oleh Perawat pada Pasien Stroke di rumah sakit Stroke Nasional (RSSN) Bukittinggi," in Seminar Nasional Keperawatan, 2019, pp. 90-94.

[10] I. Purnamasari, F. Haryanti, and Y. Soenarto, "Need Assessment Perencanaan Pulang Anak Diare," J. Keperawatan Indones., vol. 15, no. 3, pp. 255-262, 2009.

[11] E. Maryanti, S. D. Lesmana, H. Mandela, and S. Herlina, "Profil Penderita Diare Anak Di Puskesmas Rawat Inap Pekanbaru," $J$. Ilmu Kedokt., vol. 8, no. 2, p. 101, 2017.

[12] S. Yusuf, "Profil Diare di Ruang Rawat Inap Anak," Sari Pediatr., vol. 13, no. 4, p. 265, 2016.

[13] D. C. Sulistyo, N. Nurhaeni, and F. T. W, "Effect of Discharge Planning Toward Medication Adherence and Understanding of The Danger Sigms of Pneumonia of Toddlers at Indonesian Hospital," Malaysian J. Med. Res., vol. 3, no. 2, pp. 25-33, 2019.

[14] P. A. Potter, A. G. Perry, and P. Stocker, Fundamental of Nursing, 9th ed. New York: Elsevier Health Sciences, 2016.

[15] A. Nasution, R. Probowati, and A. N. Khoiri, "Self Efficacy Ibu Pada Balita Diare dengan Menggunakan Model Promosi Kesehatan," J. Ilm. Keperawatan, vol. 3, no. 2, 2017.

[16] H. Rumbo, S. Wichaikull, and B. Sanguanprasit, "Factors Influencing Preventive Behaviors of Mothers for Diarrhea in Children Aged 1-5 Years in Buol District, Indonesia," Sociol. Study, vol. 6, no. 12, pp. 745-753, 2016.

[17] L. M. M. de Sabino et al., "Validation of PrimerFor Promoting Maternal Self-Efficacy in Preventing Childhood Diarrhea," Rev. Bras. Enferm., vol. 71, no. IVC, pp. 1412-1419, 2018.

[18] I. N. G. Ba. W. Suwedia and A. Nurwahyuni, "Reduced Length of Stay in Clildren with Diarrhea Following Implementation of Clinical Pathway," in Proceedings of International Conference on Applied Science and Health, 2019, no. 4, pp. 360-367.

[19] E. Riyanti, Nurlaila, and D. Astutiningrum, "Pengaruh Edukasi Breastfeeding Ibu Post Partum Terhadap Breasfeeding Self Efficacy," J. Ilm. Kesehat. Keperawatan, vol. 14, no. 3, pp. 96104, 2018

[20] R. Forbes, A. Mandrusiak, M. Smith, and T. Russell, "Newgraduate Physical Therapists' Self-efficacy to Perform Patient Education Is Influenced by Entry-level Training Experiences," $J$. Phys. Ther. Educ., vol. 32, no. 1, 2018.

[21] A. M. Statile et al., "Improving discharge efficiency in medically complex pediatric patients," Pediatrics, vol. 138, no. 2, 2016. 